\title{
Does Ethics Reward on Public Markets: Empirical Evidences Ten Years After the Great Recession
}

\author{
Catello Giovanni Landi ${ }^{1,2}$, Valerio Rapone ${ }^{1}$, Danilo Tuccillo ${ }^{3} \&$ Andrea Rey $^{1}$ \\ ${ }^{1}$ Department of Economics, Management, Institutions, University of Naples Federico II, Naples, Italy \\ ${ }^{2}$ Interdepartmental Research Centre L.U.P.T., University of Naples Federico II, Naples, Italy \\ ${ }^{3}$ Department of Economics, University of Campania L. Vanvitelli, Caserta, Italy \\ Correspondce: Catello Giovanni Landi, Department of Economics, Management, Institutions, University of Naples \\ Federico II, Complesso Universitario Monte S. Angelo, Via Cinthia, 80126, Italy.
}

Received: February 28, 2019

Accepted: March 18, 2019

Online Published: March 28, 2019

doi:10.5430/ijba.v10n3p1

URL: https://doi.org/10.5430/ijba.v10n3p1

\begin{abstract}
In the aftermath of the last Great Recession in 2007, firms' commitment to social responsibility and sustainability started to be considered a corporate leverage to make extra-returns as well as to improve corporate reputation on institutional markets. This in turn has implied a lower uncertainty among investors and a higher trust from stakeholders' categories, rising virtuous firms' returns to over-perform their less responsible peers. Hence, this paper investigates the positive externalities of CSR on Italian stock exchange market, focusing on Blue Chips' financial performance over the ten years post-crisis. In particular, we examined whether a listed company has been rewarded by its stakeholders over a high volatility periods, leveraging on CSR and Sustainability issues. Empirical findings highlight, ceteris paribus, two implications in regards to the impact of sustainability rating on corporate financial health. Indeed, the effect of CSR and corporate sustainability improves significantly companies' earning performance (Return on Asset), although firms do not benefit from economic outperformances (Earning per Share) on stock exchange market.
\end{abstract}

Keywords: corporate social responsibility, sustainability, financial performance, listed companies, financial crisis

JEL Classification: G01, Q56, M14

\section{Introduction}

Social Finance has been experiencing a growing academic focus over last decade, with a particular interest on social rating practices meant to measure firms' ethical commitment.

Researchers and practitioners tried to highlight the impact of Corporate Social Responsibility (CSR) on the financial performance of companies, aiming at exploring the positive externalities of CSR and Sustainability on a profit-maximizing market (Moskowitz, 1972; 1975). Hence, the investors' myopia in their stock-picking has led some rating agencies to specialize on indicators supporting the investment decision-making on social and environmental issues.

Investment Theories have begun to investigate the relationship between investment returns and corporate social performance, once an investor decides to address its capitals on to socially responsible firms. This paper explores the impact of Environmental, Social and Governance factors (ESG paradigm from here on) upon financial performance of Italian listed companies. Moreover, the study highlights how investors have been building their investment portfolios, combining financial information with voluntary disclosure of Italian listed companies, concerning with sustainability and social responsibility issues.

Many empirical analyses dealt with the potential relationship between Corporate Social Performance (CSP) and firms' financial health since the 1990s, regardless of their listing markets. The purpose of this research consists in exploring the relationship between Corporate Social Performance (CSP) of the major Italian firms within FTSE-MIB index (Financial Times Stock Exchange Milano Indice di Borsa) and their Corporate Financial Performance (CFP), assessed respectively by social rating and by a double measurement: a market-based assessment "Earning per Share (EPS)" and an accounting-based measurement "Return on Asset (ROA)". 
The Italian listed companies have started to disclose their environmental and social commitment, building a valuable and intangible corporate asset. On the other side, investors have had a lot of additional information able to enhance their investments' portfolio into extra-returns. This research work investigates CSP and CFP topic through two different perspectives: the first from the investors' behavior on financial markets, once a listed firm receives an up/downgrade according to the ESG paradigm; the second from a corporate earning advantage through a socially responsible strategy.

A firm's social and environmental assessment could generate a corporate value added, since it could decrease information asymmetries on stock exchange markets, besides addressing socially responsible investments in seed financing.

Our findings partially support that CSR practices affect positively the economic performances of Italian firms, though the companies' financial performance doesn't seem to over-perform on stock exchange market. This paper fits in existing literature about the relationship between corporate social performance and corporate economic performance according to both market-based and earning-based perspective. In doing so, we developed a study on yearly corporate social assessments issued from 2008 to 2017, which disclose the companies' CSR commitment to stakeholders. Finally, we explored the impact of an ESG rating on Corporate Financial Performance, specifying the methodology underlying the assessment process of corporate sustainability.

\section{Prior Literature}

\subsection{CSP and CFP Relationship}

Academic literature has been focusing on CSR as a research field since 1980s, indeed Cochran and Wood (1984) framed CSR into a three-dimensional perspective which included responsibility, responsiveness and social issues. The impacts of social and environmental issues on corporate governance have implied new competitive strategies for a company. Hence, Clarkson et al. (2011) argued that firms disclosing their stakeholder engagement over-performed on environmental policy; whilst Barnea and Rubin (2010) pointed out a managerial immoral adoption of CSR in controversial industry sectors, given the CEOs' willingness to improve own private reputation through socially responsible practices and, as a consequence, incurring costs for shareholders.

Cai, Jo and Pan (2012) highlighted that the CSR has been applied for different corporate purposes, ranging from a more wealthy shareholding status (Friedman, 1970) to a broader economic, legal, ethical, and discretionary perspective of responsibility (Carroll, 1979).

The economic performance of responsible companies has been studied basing on a double point of view: sustainability rankings of securities and sustainability asset management companies. However, some research analyses developed on corporate sustainability performance have produced not-agreeing outcomes; some authors (Graves and Waddock, 1994; Griffin and Mahon, 1997; Margolis and Walsh, 2001; Derwall et al. 2005; Petersen and Vredenburg, 2009; Lee and Faff, 2009; Alonso-Almeida et al. 2012) highlighted a better economic performance from impact asset allocation, whereas other studies denoted that socially responsible investments gained a lower financial performance than traditional asset allocation (Hamilton et al.,1993; Lima Crisostomo et al., 2011; Statman, 2000).

In addition, Bauer et al. (2005), Goldreyer and Diltz (1999), Sauer (1997), and Schroder (2007), stated that there is not a significant difference in returns between responsible and sustainable securities and un-filtered investments according to CSR issue. Graves and Waddock (1994) showed that institutional investors address their capitals to socially responsible entities even though they are not incline to socially responsible practices. In particular, socially responsible investors choose securities within the Dow Jones Sustainability Index (DJSI), whereas others leverage on this investment portfolios aiming at enhancing their reputations. Griffin and Mahon (1997) analysed the social and financial performance of six oil companies between 1990 and 1992, discovering a positive relationship between the KLD and Fortune indices.

Margolis and Walsh (2001) compared 122 studies published between 1971 and 2001 in order to explore the positive relationship between CSR and corporate financial performance. Derwall et al. (2005) selected securities through an eco-efficiency screening, building different investment portfolios of socially high-performing and low-performing equities. They proved that a CSR screening makes a highly significant improvement in asset allocation. Petersen and Vredenburg (2009) investigated the oil sector in Canada, emphasizing the economic value related to CSR practices and showing a higher financial performance of those investments addicted to CSR. Moreover, impact investing practices experience different scenarios according to contexts where they are deployed, in fact Lee and Faff (2009) found that European and American practitioners bet upon the success of CSR firms, while on Mexican market case Alonso-Almeida et al. (2012) highlighted that firms had a positive relationship between social responsibility and 
economic performance, estimated by the Return on Equity (ROE), Return On Asset (ROA), Earnings Per Share (EPS), and price over book value (P/VL) variables.

Therefore, Mueller (1991), Hamilton et al. (1993), Statman (2000), and Lima Crisostomo et al. (2011) found adverse evidences about CSR impact on corporate performance, asserting that socially responsible mutual funds have lower performance than conventional mutual funds. In particular, Mueller (1991) analyzed the risk-adjusted returns of ten socially responsible investments from 1984 to 1988 and found that socially responsible mutual funds performed on average a yearly $1.03 \%$ less than comparable investments. Hamilton et al. (1993) estimated Jensen's Alpha of investment funds listed in the Lipper Analytical databank to examine the risk-adjusted performance of all the socially responsible mutual funds listed as of December 1990 and discovered that socially responsible mutual funds tend to exhibit similar or lower performance relative to comparable unrestricted mutual funds on a risk adjusted basis.

Landi and Sciarelli (2018) found that a CSR assessment does not have a systematic and statistically significant effect, either positive or negative, on FTSE MIB's abnormal returns, stating that "market and institutional investors do not leverage on Corporate Sustainability and Social responsibility in their stock - picking activities, but they limit their attention to typical risk factors such as EBITDA and Financial Leverage".

Goldrever and Diltz (1999) sampled a group of ethical funds, including equity, bond and balanced funds, estimating CFP through Jensen's alpha measurement, as well as Sharpe ratios and Treynor ratios, realizing that a social filter does not affect systematically the investment performance of ethical mutual funds. In addition, Statman (2000) examined the socially responsible securities within the Domini Social Index, concluding that they performed as well as the S\&P 500 index over the 1990-1998-time period.

On this ground, Lima Crisostomo et al. (2011) focused on 78 Brazilian firms from 2001 to 2006 discovering a reverse relationship between companies' social performance and their financial performance, due to the traditional financial culture in investment behaviour.

There are other research works not finding a significant difference between the performance of socially responsible companies and their market returns. Indeed, Sauer (1997) compared the DSI index to other unscreened indices, concluding that a CSR filter does not necessarily imply an adverse impact on investment returns, besides that investors can select socially responsible investments that are consistent with their value system without incurring high opportunity costs. Bauer et al. (2005) analysed 103 German, UK and US responsible mutual funds and found no statistically significant difference in returns between socially responsible and traditional mutual funds, once checked other factors, such as firms' size, book-to-market, etc. Schroder (2007) investigated whether 29 socially responsible stock indices have been outperforming compared to benchmark indices, finding no significant evidences. .

Marginalism theorists state that a positive social performance leads a firm to growing costs which lower profits and shareholder value. This is consistent with a negative relationship between firms' social performance and financial returns (Preston and O'Bannon, 1997; Waddock and Graves, 1997). This is caused by managerial opportunism, given that a company financially wealthy decreases social and environmental expenditures aiming at enhancing short-term profitability and as a consequence managers' compensations (Preston and O'Bannon, 1997).

Considering the complexity of the environment where companies operate, McWilliams and Siegel (2000) showed no outstanding relationship between social and financial performance, assuming that a corporate profit-maximizing purpose includes a social performance. As a result, each company will outsource different social and environmental benefits.

Despite some empirical researches denoting an ambiguous relationship (Alexander and Buchholz, 1978; Aupperle, et al., 1985; Cochran and Wood, 1984; Shane and Spicer, 1983; Ullman, 1985), many authors pointed out a positive relationship (McGuire et al., 1990; McGuire et al., 1988; Simpson and Kohers, 2002; Waddock and Graves, 1997; Wokutch and Spencer, 1987). Waddock and Graves (1997) bounded the uncertainty in understanding the relationship between the CSP and CFP to social performance measurement issue. Hence, they used the KLD database as a reliable assessment of U.S. firms' social performances, pointing out a significant relationship. Despite there is no theoretically foundation overlying an empirical evidence which exists between CSP and CFP, the assessments methods will result highly significant in explaining this relationship.

\subsection{CSP Measurements}

Concerning with CSP assessment, Shane and Spicer's (1983) relied for the first time on CSP measurement, mining data from the U.S. Council on Economic Priorities (CEP). Nevertheless, the lack of voluntary disclosure and reporting standards could make inconsistent a comparison among firms, even in the same industry (Shane and Spicer, 1983). 
One of the first attempt provide measures of CSP, was made in in 1994 in the US, through the use of Kinder, Lydenberg, Domini (KLD) database. The KLD database covers more than 650 corporations listed on the U.S. stock exchanges, which are assessed by a number of different indicators of social performance. KLD database was handled by an independent rating service in charge of assessing CSP by making use of a number of factors including the most typical stakeholders' concerns. Due to its innovative nature, the KLD database raised the interest of researchers (Waddock and Graves, 1997) that started to increasingly adopt it in their empirical researchers (Albinger and Freeman, 2000; Bendheim, Waddock, and Graves, 1998; Berman et al., 1999; Graves and Waddock, 1994; Greening and Turban, 2000; Griffin and Mahon, 1997; Johnson and Greening, 1999; Ruf et al., 2001; Waddock and Graves, 1997) and soon, the KLD became one of the most reliable source of social information for scholars engaged in the study of CSP in the U.S. (Hillman and Keim, 2001). In 1992, Michael Jantzi Research Associates, Inc. (MJRA) launched the Canadian Social Investment Database (CSID) as a further tool of CSP assessment in the specific case of Canadian companies. The CSID database covers more than publicly traded Canadian firms, including those traded on the Toronto Stock Exchange. The CSID assessment is made according to eight key dimensions of social performance including, but not limited to, diversity, international, product, business practices, employee relations, community.

Each dimension refers to key stakeholders' issues that should be taken into account at the corporate strategic level (Prahalad and Hamel, 1994). For each of the above dimensions, MJRA identifies main points of strength and weaknesses based on a range of different sources. Main data sources span corporate annual reports and official statements referring to issues of health and safety, ethics, environmental policies and other types of social externalities. In addition, MJRA has data access to scientific publications, press releases and articles from national press, subscription services as well as public data from government and no profit organizations. MJRA analysts also conduct direct interviews to key stakeholders, such as NGOs, trade unions and local community representatives, as well as company and industry executives and government agents. Both systems of assessment (i.e. MJRA and CSID) present similar advantages and shortcomings than KLD ratings (Griffin and Mahon, 1997; Waddock and Graves, 1997; Wood and Jones, 1995). Compared to other Canadian social responsibility ratings, the CSID index presents the advantage of more objective screening criteria for measuring social performance as well as a significant sample numerosity. Furthermore, the index presents the advantage of third party, independent rankings of all TSE 300 firms through data collected from a wide range of sources, either internal and external to the company. In a similar vein, KLD and CSID consider all CSP dimensions as impacting on final assessment in an equal way and do not use weights (Graves and Waddock, 1994). Finally, as a further limitation, this methodology only takes account of one dimension, i.e. mono-dimensional approach, which may nullify or decrease the impact of other factors on the company's CSP thus requiring a third entity to rate the industry-relevant dimensions individually. Although European countries have their own recognized ESG rating agencies (e.g. Standard Ethics; Vigeo EIRIS), only a few academic studies have focused their analyses on the impact of ESG assessment on financial performance of capitalized firms. Also, to the best of our knowledge, the most frequently used measures of listed companies' financial performance are generally limited to earning components as ROA, ROE and other Market Multiples.

As a consequence, the adoption of measures that neglect diverse accounting procedures and managerial artifices may be inconsistent. Market-based variables, as abnormal returns, are less vulnerable to them since these refer to investors' assessment and expectations about firm performance. A few empirical studies still consider firms as entities whose only aim is that of maximizing their shareholders' profits (Flammer, 2015 and Wang et al., 2015).

\section{Research Hypotheses Development}

This work develops two hypotheses affording on the literature reviewed, and it investigates them using elements that assess the relationship between CSR and CFP.

Cao et al. (2015) observed how CSR and CFP can influence the information asymmetry and the cost of equity. The results of this study have revealed that the impact of CSR on the cost of equity increases with the information asymmetry degree, considering that CSR - that supports company reputation - allows companies to "lower their cost of equity, presumably by reducing the information asymmetry and increasing investor recognition, which allows more efficient risk sharing" (Cao et al., 2015, p. 73).

Diallo and Lambey-Checchin (2016) found that CSR performance is positively related to customer trust and loyalty, employee retention, commitment, efficiency and productivity, and company image and reputation. Their results revealed that "CSR policy has short and long-term benefits, both on performance and social (in terms of trust and image)" (Diallo and Lambey-Checchin, 2016, p.15)

Finally, Timbate and Park (2018) found that CSR performance is positively related to financial reporting quality, stating that socially responsible firms are less likely to manage their earnings. The authors also said that "CSR as 
being motivated by managers' ethical incentives to serve the interests of stakeholders as opposed to the perspective that firms only engage in CSR activities that maximize shareholder value" (Timbate and Park, 2018, p.525).

According to the gaps in literature, reviewed the hypothesis to be tested is as following:

H1: Firm's CSR rating affects positively its financial performance

Focusing on the Italian context, Fiori et al. (2015) investigated the impact of CSR policies on stock prices of Italian listed companies. Using a short-term analysis, they found that a good social performance negatively influences the stock prices in the Italian stock market. The authors pointed out that this result is related to the fact that Italian listed firms have strong block-holders, stating that "the Italian investors perceive these practices as avoidable expenses reducing shareholders' income and companies' value and recognize a negative market premium, in terms of lower stock prices, to socially responsible enterprises" (Fiori et al., 2015, p.608). According this line of thought, this work develops a second hypothesis regarding the relationship between social e market performance.

H2: Firm's CSR rating affects positively its market performance

\section{Methodology}

\subsection{Sample}

We collected data from Italian companies listed on FTSE MIB index over the period 2008-2017. In particular, the sample excludes data from Italian companies that have been listed or delisted over the period 2008-2017, and it includes only those Italian companies that have remained listed throughout the entire period. As a result, our initial sample consists of 40 firms.

In addition, this study sampled only those firms that received a CSR rating issued by the Standard Ethics Agency over the entire period 2008-2017. This selection step implied a further drop in sample size to 38 firms.

\subsection{Variables}

\subsubsection{Dependent Variables Corporate Financial Performance}

Following a buy and hold approach which implies a long run investment portfolio, in this study we adopted an investment long-term timeframe. Basing on previous studies that analysed the CSP-CFP relationship, we used different proxies to measure the CFP, both accounting-based and stock market-based measurements (McGuire et al., 1988).

Scholars (Waddock and Graves, 1997; Cochran and Wood, 1984) used accounting-based proxies to evaluate the CFP because they believed that these measures were not influenced by factors unrelated to the activity of the individual firm (Shane and Spicer, 1983). The accounting-based proxies reflect the firm's historical performance and include several indicators such as Return on Asset (ROA), Return on Equity (ROE), Growth Rate of Main Operating, and Expansion Rate of Net Assets (Jun Cho et al., 2019). Therefore, to test the HP1 we used as dependent variable the ROA.

Then, other studies (Alexander and Buchholz, 1978; Vance, S.C., 1975) evaluated the CFP by stock market-based measures that refer to firms' evaluations and investors' expectations. They considered these measures more suitable to determinate the CFP because these values are considered more relevant for both investors and shareholders (Brammer and Millington, 2008). Therefore, in order to test $\mathrm{H} 2$ we used as proxy for market performance the Earning per Share (EPS) ratio.

We mined the financial and market data (ROA and EPS) from Thomson Reuters Database.

\subsubsection{Independent Variable Corporate Social Performance}

In this study, we used the sustainability rating issued by Standard Ethics Agency as proxy of CSR because of its objectivity, and its suitability to evaluate social performance of listed companies (Harjoto and Rossi, 2019).

The Standard Ethics Rating (SER) is based on five different factors regarding ethics and corporate governance system, according to the principles and recommendations of European Union (EU), United Nations (UN) and Organization for Economic Co-operation and Development (OECD).

The final scores indicated by SER are expressed through nine different SER classes. SER assigns the highest score i.e. a triple $\mathrm{E}$ (EEE) - when there is a full strong compliance with the values expressed by the UN, OECD and EU, and a strong ability to manage risks; the lowest score - i.e. an F - is assigned when a firm reaches the lowest level of compliance and ability to manage reputational risks linked to principles of UN, OECD and EU. Finally, the companies which do not comply with the principles issued by EU, UN and OECD or do not release enough 
information, do not receive ratings. In this case, SER included these companies amongst the "pending" or "suspending" firms.

After we collected the SER ratings, converting them into an ordinal scale from 0 ("suspended "or "pending") to 9 (EEE). Therefore, the independent variable CSR can range from 0 to 9. Table 1 summarizes the procedure of conversion from SER Index to CSR assessments.

Table 1. Conversion from SER index values to CSR values

\begin{tabular}{clc}
\hline $\begin{array}{c}\text { SER } \\
\text { Index }\end{array}$ & \multicolumn{1}{c}{ Description } & CSR \\
\hline EEE & $\begin{array}{l}\text { Full strong compliance with the values expressed by the United Nations, OECD and EU and, } \\
\text { strong ability to manage risks. The highest rating. }\end{array}$ & 9 \\
\hline EEE- & $\begin{array}{l}\text { Excellent strong compliance with the values expressed by the United Nations, OECD and EU, } \\
\text { and, strong ability to manage risks }\end{array}$ & 8 \\
\hline EE+ & $\begin{array}{l}\text { Very strong compliance and ability to manage reputational risks linked to United Nations, OECD } \\
\text { and EU agenda on sustainability and corporate governance }\end{array}$ & 7 \\
\hline EE & $\begin{array}{l}\text { Strong compliance and ability to manage reputational risks linked to United Nations, OECD and } \\
\text { EU agenda on sustainability and corporate governance, but somewhat susceptible to changes in } \\
\text { circumstances }\end{array}$ & 6 \\
\hline EE- & $\begin{array}{l}\text { Adequate compliance and ability to manage reputational risks linked to United Nations, OECD } \\
\text { and EU agenda on sustainability and corporate governance, but more subject to changes in } \\
\text { circumstances }\end{array}$ & 5 \\
\hline $\mathbf{E +}$ & $\begin{array}{l}\text { Low compliance and ability to manage reputational risks linked to United Nations, OECD and EU } \\
\text { agenda on sustainability and corporate governance, but with margins of improvement to get into } \\
\text { the "compliance zone" }\end{array}$ & 4 \\
\hline $\mathbf{E}$ & $\begin{array}{l}\text { Low compliance and ability to manage reputational risks linked to United Nations, OECD and EU } \\
\text { agenda on sustainability and corporate governance }\end{array}$ & 3 \\
\hline $\mathbf{E - ~}$ & $\begin{array}{l}\text { Very Low compliance and ability to manage reputational risks linked to United Nations, OECD } \\
\text { and EU agenda on sustainability and corporate governance }\end{array}$ & 2 \\
\hline $\mathbf{F}$ & $\begin{array}{l}\text { Lowest level of compliance and ability to manage reputational risks linked to United Nations, } \\
\text { OECD and EU agenda on sustainability and corporate governance }\end{array}$ & 1 \\
\hline Pending & $\begin{array}{l}\text { No complaint with the values expressed by the EU, UN and OECD or that do not release enough } \\
\text { information }\end{array}$ & 0 \\
\hline Source: STANDARD ETHICS &
\end{tabular}

The values of CSR variable receive a yearly update, besides rating agencies can downgrade or upgrade companies social commitment during the year, because of events of significant magnitude. Nevertheless, the study is independent from these possible variations, because one of the basic assumptions of the statistical model used is the permanent presence of the same sample units to various years of analysis.

\subsubsection{Control Variables}

The study also used control variables. As measure for size, we used the log-transformed of total asset (lnTA). We expect a positive impact of total asset because larger firms may have adopted CSR guidelines to engage all stakeholders (Burke and Logsdon, 1986). Cheng et al. (2014) argued that CSR reduces the cost of debt by increasing transparency. So, we adopt the ratio Debt/Equity (D/E) as risk dimension. Since the firm's value is also function of growth and profitability (Palepu et al., 1996) we employed the reinvestment rate (RR) to measure the growth, and the ratio EBITDA/Total equity (EBITDA/E) to measure the profitability. Table 2 summarises the variables used. 
Table 2. Variables definition

\begin{tabular}{|c|c|c|c|c|c|}
\hline Variable & Definition & Data Source & & $\begin{array}{l}\text { Expected } \\
\text { direction }\end{array}$ & Hypotheses \\
\hline \multirow[t]{2}{*}{$\begin{array}{l}\text { ROA } \\
\text { (dependent) }\end{array}$} & Return on Asset & $\begin{array}{l}\text { Thomson } \\
\text { Database }\end{array}$ & Reuters & & H1 \\
\hline & $=$ Net Income/Total Assets & & & & \\
\hline \multirow{3}{*}{$\begin{array}{l}\text { EPS } \\
\text { (dependent) }\end{array}$} & Earning per Share & Thomson & Reuters & & $\mathrm{H} 2$ \\
\hline & Income-Preferred & & & & \\
\hline & $\begin{array}{l}\text { Dividends)/Weighted } \\
\text { Common Shares }\end{array}$ & & & & \\
\hline \multirow{10}{*}{$\begin{array}{l}\text { CSR } \\
\text { (independent) }\end{array}$} & $\mathrm{EEE}=9$ & Standard & Ethics & + & H1 \\
\hline & EEE- $=8$ & Agency & & & $\mathrm{H} 2$ \\
\hline & $\mathrm{EE}+=7$ & & & & \\
\hline & $\mathrm{EE}=6$ & & & & \\
\hline & $\mathrm{EE}-=5$ & & & & \\
\hline & $E+=4$ & & & & \\
\hline & $E=3$ & & & & \\
\hline & $\mathrm{E}-=2$ & & & & \\
\hline & $\mathrm{F}=1$ & & & & \\
\hline & Suspending $=0$ & & & & \\
\hline \multirow{2}{*}{$\begin{array}{l}\text { InTA } \\
\text { (control) }\end{array}$} & Natural Logarithm (Total Asset) & Thomson & Reuters & + & H1 \\
\hline & & Database & & & $\mathrm{H} 2$ \\
\hline \multirow{2}{*}{$\begin{array}{l}\mathbf{D} / \mathbf{E} \\
\text { (control) }\end{array}$} & Total Debt/Total Equity & Thomson & Reuters & + & H1 \\
\hline & & Database & & & $\mathrm{H} 2$ \\
\hline \multirow{2}{*}{$\begin{array}{l}\text { EBITDA/E } \\
\text { (control) }\end{array}$} & EBITDA/Total Equity & Thomson & Reuters & + & H1 \\
\hline & & Database & & & $\mathrm{H} 2$ \\
\hline \multirow{3}{*}{$\begin{array}{l}\mathbf{R R} \\
\text { (control) }\end{array}$} & Reinvestment Rate & Thomson & Reuters & + & H1 \\
\hline & & Database & & & $\mathrm{H} 2$ \\
\hline & $=$ Retained Earnings/Current Earnings & & & & \\
\hline
\end{tabular}

\subsection{Analysis and Discussion of Results}

In order to validate our hypotheses, we run a Panel Data Analysis that included 404 observations of 38 companies over a period of 10 years.

The general regression models are based on the following equations, whose pattern takes into account all independent and control factors (Table. 3).

Specifically, to test the $\mathrm{H} 1$ we applied the following linear regression model:

$$
R O A_{i, t}=\alpha_{0}+\alpha_{1} C S R_{1, t}+\alpha_{2} \ln T A_{i, t}+\alpha_{3} D / E_{i, t}+\alpha_{4} E B I T D A / E_{i, t}+\alpha_{5} R R_{i, t}+\varepsilon_{i, t}
$$

Subsequently, to test the $\mathrm{H} 2$ we used this second linear regression model:

$$
E P S_{i, t}=\alpha_{0}+\alpha_{1} \operatorname{CSR}_{1, t}+\alpha_{2} \operatorname{lnT} A_{i, t}+\alpha_{3} D / E_{i, t}+\alpha_{4} E B I T D A / E_{i, t}+\alpha_{5} R R_{i, t}+\varepsilon_{i, t}
$$

Table 3. Descriptive statistics

\begin{tabular}{lcccc}
\hline & Minimum & Mean & Maximum & Dev St \\
\hline ROA & -0.191 & 0.053 & 0.373 & 0.073 \\
\hline EPS & -642.940 & 0.408 & 468.390 & 46.762 \\
\hline CSR & 0.000 & 3.457 & 8.000 & 2.416 \\
\hline EBITDA/E & -0.765 & 0.474 & 11.605 & 0.956 \\
\hline D/E & 0.000 & 2.056 & 17.279 & 2.600 \\
\hline $\ln T A$ & 5.339 & 9.714 & 13.860 & 1.946 \\
\hline RR & & 0.101 & 11.411 & 0.790 \\
\hline
\end{tabular}


As known, Panel data analysis can follow three independent approaches:

- independently pooled panels,

- random effects models (RE), or

- fixed effects models (FE).

Our estimated models through FE and RE explain the dependent variable in different ways. The FE estimates the individual effects which are considered fixed, they are de facto included as explanatory variables or rather individual constants. As opposed, the RE estimated individual effects are a component of the error. Running only a specific test, Hausman (1978), can test the hypothesis of no correlation between the individual effects and the explanatory variables, as well as the ability to estimate the reliability of RE estimator. The Hausman test is used to compare two estimators, one of which is consistent both under the null hypothesis of no correlation under the alternative hypothesis, while the other is consistent (and efficient) only under the null hypothesis and inconsistent under the alternative hypothesis.

Statistically, fixed effects are always a reasonable model to develop through panel data, but they may not be the most efficient model to run. Random effects will give you better P-values as they are a more efficient estimator, so you should run random effects if it is statistically justifiable to do so.

The Hausman H-test (Table. 5 and Table. 8) checks a more efficient model against a less efficient but consistent model to make sure that the more efficient model also gives consistent. The Hausman H-test probes the null hypothesis that the coefficients estimated by the efficient random effects estimator are the same as the ones estimated by the consistent fixed effects estimator.

The results of Panel Data Analysis - Random Effects are reported below:

Table 4. Panel data results of ROA (Hypothesis 1)

\begin{tabular}{|c|c|c|c|c|c|c|}
\hline \multirow[b]{2}{*}{ ROA } & \multirow[b]{2}{*}{$\begin{array}{l}\text { Expected } \\
\text { Direction }\end{array}$} & \multirow[b]{2}{*}{ Coeff. } & \multirow[b]{2}{*}{ E.S. } & \multirow[b]{2}{*}{ Sig. } & \multicolumn{2}{|c|}{ 95\% Conf. Interval } \\
\hline & & & & & Lower & Upper \\
\hline CSR & + & $.003 * * *$ & .001 & 0.016 & .001 & .006 \\
\hline $\operatorname{lnTA}$ & + & .007 & .005 & 0.159 & -.003 & .018 \\
\hline $\mathrm{D} / \mathrm{E}$ & + & -.001 & .002 & 0.891 & -.004 & .003 \\
\hline EBITDA/E & + & $-.021 * * *$ & .004 & 0.000 & -.029 & -.013 \\
\hline RR & + & $.029 * * *$ & .006 & 0.000 & .181 & .040 \\
\hline cons & & $.239 * * *$ & .036 & 0.000 & .168 & .301 \\
\hline N.Observations & 404 & & & & & \\
\hline$R^{2}$ Overall & $\mathbf{0 . 3 8 3 3}$ & & & & & \\
\hline Wald chi ${ }^{2}$ & $183.99 * * *$ & & & & & \\
\hline
\end{tabular}

Table 5. Hausman test (H1)

\begin{tabular}{|c|c|c|c|c|}
\hline & \multicolumn{4}{|c|}{ Coefficients } \\
\hline & (b) fe & (B) random & $\begin{array}{c}(\mathrm{b}-\mathrm{B}) \\
\text { Difference }\end{array}$ & $\begin{array}{c}\text { sqrt (diag(V_b-V_B }) \\
\text { S.E. }\end{array}$ \\
\hline Corporate-E & .003 & .003 & -.001 & .000 \\
\hline EBIDTA/E & .007 & .008 & .002 & .001 \\
\hline $\mathrm{D} / \mathrm{E}$ & .004 & -.002 & .006 & .000 \\
\hline $\operatorname{lnTA}$ & -.021 & -.021 & -.000 & .006 \\
\hline $\mathrm{RR}$ & .030 & .029 & .000 & .001 \\
\hline $\begin{array}{l}\text { Test : H0: di } \\
\text { Chi }^{2}=1.02 *\end{array}$ & t syste & & & \\
\hline
\end{tabular}

According to H-test results, is possible to see that a Random Effects Analysis is more appropriate in this case. In fact, being Prob $>\mathrm{Chi}^{2}=0.0000$, the null hypothesis has to be rejected.

It was carried out the Breusch and Pagan Lagrangian multiplier test (Table. 6) for Random Effects aiming at 
understanding the most appropriate type of analysis meant to test the significance of the ESG Rating impact on companies' returns under investigation. The null hypothesis underlying the test is that individual-specific or time-specific error variance components are zero. If the null hypothesis is not rejected, the pooled OLS is preferred; otherwise, the random effect model is better. In our case study the test shows the presence of the random effects, being the $P$-value equal to zero.

The findings carried out through our random effect model show a positive and significant impact of ESG rating on corporate financial performance [CSR: p<0.05_Table. 4]; whilst a not systematic improvement on corporate market performance [CSR: p>0.05_Table 7]. As specified above, we developed two different analyses, testing how CSR can affect a listed company's performance on real market side in regards to earnings gained (ROA); and on financial market side considering the value and total amount of outstanding shares on stock exchange (EPS). Moreover, being capital allocation on regulated markets supported by fundamental analysis tools, institutional investors do not take into consideration additional information not strictly financial, such as ESG ratings. The variables still having a significant impact on financial and market performances remain those classical indicators reflecting asset management in regards to ROA [EBITDA/E $\mathrm{p}<0.01$ and RR $\mathrm{p}<0.01$ _Table. 4] and risk management concerning with ESP $\left[\operatorname{lnTA} p<0.01 \_D / E \mathrm{p}<0.01 \_E B I T D A / E \mathrm{p}<0.05 \_R R \mathrm{p}<0.01 \_\right.$Table. 7].

Table 6. Breusch and pagan lagrangian test $(\mathrm{H} 2)$

\begin{tabular}{|c|c|c|}
\hline & 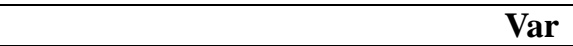 & Sd= sqrt (Var) \\
\hline ROA & .005 & .0735 \\
\hline $\mathrm{e}$ & .002 & .041 \\
\hline $\mathrm{u}$ & .002 & .044 \\
\hline Test: $\operatorname{Var}(u)=0$ & $\operatorname{Chi}^{2}(01)=486.94 * * *$ & \\
\hline
\end{tabular}

$* * *, * *, *$ denote significance at the $1 \%, 5 \%$ and $10 \%$ level, respectively.

The results of Panel Data Analysis - Fixed Effects are reported below:

Table 7. Panel data results of EPS (Hypothesis 2)

\begin{tabular}{|c|c|c|c|c|c|c|}
\hline \multirow[b]{2}{*}{ EPS } & \multirow[b]{2}{*}{$\begin{array}{l}\text { Expected } \\
\text { Direction }\end{array}$} & \multirow[b]{2}{*}{ Coeff. } & \multirow[b]{2}{*}{ E.S. } & \multirow[b]{2}{*}{ Sig. } & \multicolumn{2}{|c|}{$95 \%$ Conf. Interval } \\
\hline & & & & & Lower & Upper \\
\hline CSR & + & -.763 & 1.483 & 0.607 & -3.681 & 2.153 \\
\hline $\operatorname{lnTA}$ & + & $26.528 * * *$ & 5.942 & 0.000 & 14.841 & 38.215 \\
\hline $\mathrm{D} / \mathrm{E}$ & + & $-22.235 * * *$ & 2.131 & 0.000 & -26.425 & -18.044 \\
\hline EBITDA/E & + & $20.698 * *$ & 8.174 & 0.012 & 4.623 & 36.772 \\
\hline RR & + & $-33.877 * * *$ & 6.290 & 0.000 & -46.246 & -21.507 \\
\hline cons & & -160.119 & 76.352 & 0.037 & -310.270 & -9.968 \\
\hline N.Observations & 404 & & & & & \\
\hline$R^{2}$ Overall & 0.0692 & & & & & \\
\hline Model F & $2.03 * * *$ & & & & & \\
\hline
\end{tabular}

Table 8. Hausman test (H2)

\begin{tabular}{|c|c|c|c|c|}
\hline & \multicolumn{4}{|c|}{ Coefficients } \\
\hline & (b) fe & (B) & (b-B) & sqrt (diag(V_b-V_B) \\
\hline & & re & Difference & S.E. \\
\hline Corporate-E & -.763 & -1.197 & .434 & .952 \\
\hline EBIDTA/E & 26.528 & 7.847 & 18.680 & 3.963 \\
\hline $\mathrm{D} / \mathrm{E}$ & -22.235 & -6.623 & -15.611 & 1.775 \\
\hline $\operatorname{lnTA}$ & 20.698 & 5.553 & 15.144 & 7.990 \\
\hline RR & -33.877 & -7.003 & -26.874 & 3.332 \\
\hline
\end{tabular}

Test: H0: difference in coefficient not systematic

$\mathrm{Chi}^{2}=77.35 * * *$

$* * *, * *, *$ denote significance at the $1 \%, 5 \%$ and $10 \%$ level, respectively. 


\section{Conclusion}

This research focuses on a widely addressed topic dealing with the relationship between firms' social performance and financial performance, and how CSR can affect companies' financial wealth. Previous literature highlighted divergent and, in some cases, not-agreeing empirical findings, considering the different measurements underlying corporate social and financial performance and the reference market of firms.

Our results comply, at some levels, to previous empirical studies supporting the thesis that social responsibility and sustainability are still a not reliable corporate leverages to enhance companies' market value, and as a consequence an extra-return for investors in terms of EPS. Conversely, companies' financial health not related to stock exchange dynamics but to accounting-based measurement like ROA seems to be more performing, as if consumers or other entities belonging to the same business ecosystem were more responsive to corporate social and environmental commitment.

Through our analysis, we found a misalignment between firms' business environment (H1) and stock exchange market where they are listed (H2), and this could be considered an unusual effect given that our CSR assessments are mainly addressed to institutional investors. This situation still denotes an existing information asymmetry about CSR and sustainability disclosure on Italian stock exchange market, due to the high transaction costs to get extra-financial information on this ground meant to decrease market uncertainty in socially responsible investing. Moreover, despite the growth rate of the Impact Investments in Europe during last two years (SRI Study 2018, EUROSIF), these investment classes seem to be allocated towards less institutional markets, addressing to contexts more oriented to firms and consumers environment.

Thus and basing on our empirical evidence, Italian listed companies could leverage on their social and environmental strategies as a source of competitive advantage, since a firm can increase its returns on asset disclosing its responsible commitment on real market. In fact, given that our first hypothesis points out an improvement in return on asset, this performance measurement is in turn strongly affected by corporate income situation or by the assets a firm owns, which mainly characterizes its business environment rather than a financial market.

\section{References}

Albinger, H.S., \& Freeman, S.J. (2000). Corporate social performance and attractiveness as an employer to different job seeking populations. Journal of Business Ethics, 28(3), 243-253. https://doi.org/10.1023/A:1006289817941

Alexander, G.J., \& Buchholz, R.A. (1978). Corporate social responsibility and stock market performance. Academy of Management Journal, 21(3), 479-486. https://doi.org/10.5465/255728

Alonso-Almeida, M.D.M., Rodríguez-Antón, J.M., \& Rubio-Andrada, L. (2012). Reasons for implementing certified quality systems and impact on performance: an analysis of the hotel industry. The Service Industries Journal, 32(6), 919-936. https://doi.org/10.1080/02642069.2010.545886

Aupperle, K.E., Carroll, A.B., \& Hatfield, J.D. (1985). An empirical examination of the relationship between corporate social responsibility and profitability. Academy of Management Journal, 28(2), 446-463. https://doi.org/10.5465/256210

Barnea, A., \& Rubin, A. (2010). Corporate social responsibility as a conflict between shareholders. Journal of Business Ethics, 97(1), 71-86. https://doi.org/10.1007/s10551-010-0496-z

Bauer, H.H., Reichardt, T., Barnes, S.J., \& Neumann, M.M. (2005). Driving consumer acceptance of mobile marketing: A theoretical framework and empirical study. Journal of Electronic Commerce Research, 6(3), 181.

Berman, S.L., Wicks, A.C., Kotha, S., \& Jones, T.M. (1999). Does stakeholder orientation matter? The relationship between stakeholder management models and firm financial performance. Academy of Management Journal, 42(5), 488-506. https://doi.org/10.5465/256972

Brammer, S., \& Millington, A. (2008). Does it pay to be different? An analysis of the relationship between corporate social and financial performance. Strategic Management Journal, 29(12), 1325-1343. https://doi.org/10.1002/smj.714

Cai, Y., Jo, H., \& Pan, C. (2012). Doing well while doing bad? CSR in controversial industry sectors. Journal of Business Ethics, 108(4), 467-480. https://doi.org/10.1007/s10551-011-1103-7

Cao, Y., Myers, J. N., Myers, L.A., \& Omer, T.C. (2015). Company reputation and the cost of equity capital. Review of Accounting Studies, 20(1), 42-81. https://doi.org/10.1007/s11142-014-9292-9

Carroll, A.B. (1979). A three-dimensional conceptual model of corporate performance. Academy of Management Review, 4(4), 497-505. https://doi.org/10.5465/amr.1979.4498296 
Cheng, B., Ioannou, I., \& Serafeim, G. (2014). Corporate social responsibility and access to finance. Strategic Management Journal, 35(1), 1-23. https://doi.org/10.1002/smj.2131

Clarkson, P.M., Li, Y., Richardson, G.D., \& Vasvari, F.P. (2011). Does it really pay to be green? Determinants and consequences of proactive environmental strategies. Journal of Accounting and Public Policy, 30(2), 122-144. https://doi.org/10.1016/j.jaccpubpol.2010.09.013

Cochran, P.L., \& Wood, R.A. (1984). Corporate social responsibility and financial performance. Academy of Management Journal, 27(1), 42-56. https://doi.org/10.5465/255956

Derwall, J., Guenster, N., Bauer, R., \& Koedijk, K. (2005). The eco-efficiency premium puzzle. Financial Analysts Journal, 51-63. https://doi.org/10.2469/faj.v61.n2.2716

Diallo, M.F., \& Lambey-Checchin, C. (2016, July). Relationships between CSR and customer loyalty: what lessons for retailers?. RIODD 2016.

European Sustainable Investment Forum-SRI Study. (2018). Retrieved from http://www.eurosif.org/wp-content/uploads/2018/11/European-SRI-2018-Study.pdf

Fiori, G., di Donato, F., \& Izzo, M.F. (2015). Corporate Social Responsibility and Stock Prices: A Study on the Italian Market. Corporate Ownership \& Control, 608. https://doi.org/10.22495/cocv12i2c6p3

Flammer, C. (2015). Does corporate social responsibility lead to superior financial performance? A regression discontinuity approach. Management Science, 61(11), 2549-2568. https://doi.org/10.1287/mnsc.2014.2038

Friedman, M. (2007). The social responsibility of business is to increase its profits. In Corporate ethics and corporate governance (pp. 173-178). Springer, Berlin, Heidelberg.

Goldreyer, E.F., \& Diltz, J.D. (1999). The performance of socially responsible mutual funds: incorporating sociopolitical information in portfolio selection. Managerial Finance, 25(1), 23-36. https://doi.org/10.1108/03074359910765830

Graves, S.B., \& Waddock, S.A. (1994). Institutional owners and corporate social performance. Academy of Management Journal, 37(4), 1034-1046. https://doi.org/10.2307/256611

Greening, D.W., \& Turban, D.B. (2000). Corporate social performance as a competitive advantage in attracting a quality workforce. Business \& Society, 39(3), 254-280. https://doi.org/10.1177/000765030003900302

Griffin, J.J., \& Mahon, J.F. (1997). The corporate social performance and corporate financial performance debate: Twenty-five years of incomparable research. Business \& Society, 36(1), 5-31. https://doi.org/10.1177/000765039703600102

Hamilton, S., Jo, H., \& Statman, M. (1993). Doing well while doing good? The investment performance of socially responsible mutual funds. Financial Analysts Journal, 49(6), 62-66. https://doi.org/10.2469/faj.v49.n6.62

Harjoto, M.A., \& Rossi, F. (2019). Religiosity, female directors, and corporate social responsibility for Italian listed companies. Journal of Business Research, 95, 338-346. https://doi.org/10.1016/j.jbusres.2018.08.013

Hausman, J.A. (1978). Specification tests in econometrics. Econometrica: Journal of the Econometric Society, 1251-1271. https://doi.org/10.2307/1913827

Hillman, A.J., \& Keim, G.D. (2001). Shareholder value, stakeholder management, and social issues: what's the bottom $\begin{array}{llll}\text { line?. } & \text { Strategic } & \text { Management }\end{array}$ https://doi.org/10.1002/1097-0266(200101)22:2<125::AID-SMJ150>3.0.CO;2-H

Johnson, R.A., \& Greening, D.W. (1999). The effects of corporate governance and institutional ownership types on corporate social performance. Academy of Management Journal, 42(5), 564-576. https://doi.org/10.5465/256977

Jun Cho, S., Young Chung, C., \& Young, J. (2019). Study on the Relationship between CSR and Financial Performance. Sustainability, 11(2), 343. https://doi.org/10.3390/su11020343

Landi, G., \& Sciarelli, M. (2018). Towards a more ethical market: the impact of ESG rating on corporate financial performance. Social Responsibility Journal. https://doi.org/10.1108/SRJ-11-2017-0254

Lee, D.D., \& Faff, R.W. (2009). Corporate sustainability performance and idiosyncratic risk: A global perspective. Financial Review, 44(2), 213-237. https://doi.org/10.1111/j.1540-6288.2009.00216.x

Lima Crisóstomo, V., de Souza Freire, F., \& Cortes de Vasconcellos, F. (2011). Corporate social responsibility, firm value and financial performance in Brazil. Social Responsibility Journal, 7(2), 295-309. https://doi.org/10.1108/SRJ-09-2016-0153

Margolis, J.D., \& Walsh, J.P. (2001). People and profits: The search for a link between a company's social and 
financial performance. Psychology Press. https://doi.org/10.2307/3556659

McGuire, J.B., Schneeweis, T., \& Branch, B. (1990). Perceptions of firm quality: A cause or result of firm performance. Journal of Management, 16(1), 167-180. https://doi.org/10.1177/014920639001600112

McGuire, J.B., Sundgren, A., \& Schneeweis, T. (1988). Corporate social responsibility and firm financial performance. Academy of Management Journal, 31(4), 854-872. https://doi.org/10.5465/256342

McWilliams, A., \& Siegel, D. (2000). Corporate social responsibility and financial performance: correlation or $\begin{array}{llll}\text { misspecification? Strategic } & \text { Management }\end{array}$ https://doi.org/10.1002/(SICI)1097-0266(200005)21:5<603::AID-SMJ101>3.0.CO;2-3

Moskowitz, M. (1972). Choosing socially responsible stocks. Business and Society Review, 1(1), 71-75.

Moskowitz, M. (1975). Profiles in corporate responsibility: The ten worst and the ten best. Business and Society Review, 13(8), 42.

Mueller, S.A. (1991). The opportunity cost of discipleship: Ethical mutual funds and their returns. Sociological Analysis, 52(1), 111-124. https://doi.org/10.2307/3710719

Petersen, H., \& Vredenburg, H. (2009). Corporate governance, social responsibility and capital markets: exploring the institutional investor mental model. Corporate Governance: The International Journal of Business in Society, 9(5), 610-622. https://doi.org/10.1108/14720700910998175

Prahalad, C.K., \& Hamel, G. (1994). Competing for the Future (Vol. 25). Boston: Harvard Business School Press.

Preston, L.E., \& O'bannon, D.P. (1997). The corporate social-financial performance relationship: A typology and analysis. Business \& Society, 36(4), 419-429. https://doi.org/10.1177/000765039703600406

Ruf, B.M., Muralidhar, K., Brown, R.M., Janney, J.J., \& Paul, K. (2001). An empirical investigation of the relationship between change in corporate social performance and financial performance: A stakeholder theory perspective. Journal of Business Ethics, 32(2), 143-156. https://doi.org/10.1023/A:1010786912118

Sauer, D.A. (1997). The impact of social-responsibility screens on investment performance: Evidence from the Domini 400 Social Index and Domini Equity Mutual Fund. Review of Financial Economics, 6(2), 137-149. https://doi.org/10.1016/S1058-3300(97)90002-1

Schröder, M. (2007). Is there a difference? The performance characteristics of SRI equity indices. Journal of Business Finance \& Accounting, 34(1-2), 331-348. https://doi.org/10.1111/j.1468-5957.2006.00647.x

Shane, P.B., \& Spicer, B.H. (1983). Market response to environmental information produced outside the firm. The Accounting Review, 58(3), 521.

Simpson, W.G., \& Kohers, T. (2002). The link between corporate social and financial performance: Evidence from the banking industry. Journal of Business Ethics, 35(2), 97-109. https://doi.org/10.1023/A:1013082525900

Statman, M. (2000). Socially responsible mutual funds (corrected). Financial Analysts Journal, 56(3), 30-39. https://doi.org/10.2469/faj.v56.n3.2358

Timbate, L., \& Park, C. (2018). CSR Performance, Financial Reporting, and Investors' Perception on Financial Reporting. Sustainability, 10(2), 522. https://doi.org/10.3390/su10020522

Ullmann, A.A. (1985). Data in search of a theory: A critical examination of the relationships among social performance, social disclosure, and economic performance of US firms. Academy of Management Review, 10(3), 540-557. https://doi.org/10.5465/amr.1985.4278989

Vance, S.C. (1975). Are socially responsible corporations good investment risks. Management Review, 64(8), 19-24.

Waddock, S.A., \& Graves, S.B. (1997). The corporate social performance-financial performance link. Strategic Management Journal, 303-319. https://doi.org/10.1002/(SICI)1097-0266(199704)18:4<303::AID-SMJ869>3.0.CO;2-G

Wang, Q., Dou, J., \& Jia, S. (2016). A meta-analytic review of corporate social responsibility and corporate financial performance: The moderating effect of contextual factors. Business \& Society, 55(8), 1083-1121. https://doi.org/10.1177/0007650315584317

Wokutch, R.E., \& Spencer, B.A. (1987). Corporate saints and sinners: The effects of philanthropic and illegal activity on organizational performance. California Management Review, 29(2), 62-77. https://doi.org/10.2307/41165239

Wood, D.J., \& Jones, R.E. (1995). Stakeholder mismatching: A theoretical problem in empirical research on corporate social performance. The International Journal of Organizational Analysis, 3(3), 229-267. https://doi.org/10.1108/eb028831 